\title{
Assessment of the Impact of the Functioning of the FIFO on the Occurrence of Organic Products with an Exceeded Use-By Date
}

* $\quad$ Faculty of Human Nutrition, Warsaw University of Life Sciences

* Departament of Functional and Organic Food, Faculty of Human Nutrition, Warsaw University of Life Sciences e-mail: malgorzataa.pikora@gmail.com

\section{Keywords:}

FIFO, organic food, food waste, food storage logistics, food retail

\begin{abstract}
Food waste is a global problem with $5 \%$ of the European Union's (EU's) retail sector responsible. The reasons cited for food waste at retail level among others: undesirable customer behaviour, inadequate packaging, irregular demand, overestimated deliveries, small store area and warehouse space, inappropriate replenishment policies in shops and increased product quality requirements. The requirement to keep shelves full in stores and inappropriate storage logistics lead to overstocking of products, the arrangement of which disregards the first in-first out (FIFO) principle. It contributes to the amplification of food take-offs and may lead to the occurrence of products with exceeded use-by dates, which is the most common cause of food wastage [Federacja Polskich Banków Żywności 2020]. The aim of the study was to evaluate the functioning of the FIFO system in specialist stores, discount stores and large-format stores that have organic food on offer. To evaluate the FIFO system, unannounced inspections were conducted in the stores. During the inspections, errors in the arrangement of products according to the FIFO system were detected. The items found to be out of order were both long and short-dated products, stored in refrigerated as well as on regular shelves, indicating that stores have a problem with storage logistics in all departments. Improving solutions and implementing appropriate measures in this area could reduce food wastage at the retail level.
\end{abstract}

(c) IOŚ-PIB

\section{INTRODUCTION}

Food waste can be viewed as an unintended and unavoidable consequence of supply chain operations, even though products declared as food waste may be edible if better managed throughout the supply chain and especially at the retail store level [Teller et al. 2018].

Food waste is a problem not only in households but also at the retail level. The reasons for the occurrence of food wastage in stores include: undesirable customer behaviour, irregular demand, incorrect activities of stores in the field of replenishment policy, small store area and warehouse space, overestimation of deliveries and increased product quality requirements [Wrzosek et al. 2014; Hermsdorf et al. 2017; Teller et al. 2018; Federacja Polskich Banków Żywności 2020]. In the case of dairy products, the probable factors determining the level of losses were: mechanical strength of packaging and shelf life [Kołożyn-Krajewska et al. 2014].

It is estimated that in the EU countries, the retail sales sector generates food waste amounting to approximately $5 \%$ of total food waste. In the UK, the food retail market generates around 0.2 million tonnes of food waste, which is around $2 \%$ of the total amount of waste generated annually by the domestic food supply. In Germany and Sweden, the situation is similar - it is about 3-4\% [Filimonau and Gherbin 2017].

Inadequate packaging, which is easily deformed and prone to mechanical damage, is defined as a factor contributing to the generation of food waste [Verghese et al. 2015]. Improved packaging systems to provide better product protection should be one way of reducing food waste. Particular attention should be paid to: better protection against damage and ventilation and temperature control, as well as the use of packaging materials and technologies that will extend the shelf life [Wikstrom et al. 2014]. The report $A$ Global Language for Packaging and Sustainability noted that intelligent packaging and sharing of product data can enable a more synchronised value chain with greater visibility and traceability [A Global Language for Packaging and Sustainability 2011]. At the same time, Hermsdorf et al. showed that lowering the quality standards - allowing products with damaged 
and incomplete packaging, and fresh products (fruits and vegetables) with defects that do not affect food safety to be sold - may contribute to reducing food waste [Hermsdorf et al. 2017].

Wrzosek et al. showed that the greatest waste of dairy products were generated in discount stores. Much smaller amounts of food waste were reported in local stores and small supermarkets. Moreover, it was shown that the most common cause of food waste was exceeding the use-by date, $78 \%$, while mechanical damage to packaging was responsible for $22 \%$ of cases. It is also shown that $40 \%$ of dairy product waste was caused by exceeding the date of minimum durability (yoghurts and sour cream), while $60 \%$ by package damage. The lowest wastes were recorded for products packed in cartons - UHT (ultra-high temperature processing) milk and cream [Wrzosek et al. 2014].

Research in the areas of retail sales, operations management and store logistics mainly focusses on the availability of products on the shelves and proper display and prevention of stock depletion. Among the scientific reports, there is a large group of studies on the effectiveness of retail trade, stock replenishment processes and operational processes [Corsten and Gruen 2003; Vijayan 2014; Teller et al. 2018; Wei et al. 2020]. The occurrence of food waste in stores and the related wasting of food is a subject that is discussed much less frequently [Trautrims et al. 2009; Teller et al. 2018; Mendes et al. 2020].

One of the factors causing the loss of food is also noncompliance with the FIFO principle [Hermsdorf et al. 2017; Teller et al. 2018]. The FIFO strategy is most often used in the field of logistics because it represents a logical basis for thinking; it is based on the date the product was introduced to its storage location. The FIFO method can be applied to all types of products - food and non-food because it does not take into account the deterioration in product quality and price changes depending on its useful life [Bertolini et al. 2013; Derqui et al. 2016].

Recommendations for reducing food waste in stores are closely related to the FIFO procedure, as they indicate it as an inventory method. It is also used during inventory control and verification of use-by dates on warehouses and store shelves [Teller et al. 2018].

The aim of the research was to assess the functioning of FIFO in specialist stores - with healthy and ecological food as well as in conventional stores (large-format stores and discount stores) offering ecological products. Organic food, due to its specific production method, is more expensive than conventional food. The limited possibility of using additional substances, including preservatives, may result in a shorter use-by date [Staniak 2014]. The study by Grzybowska-Brzezińska and colleagues showed that one of the factors limiting the purchase of organic products is their too-high price, lack of trust in the technology of obtaining raw material and limited availability of products in retail trade [GrzybowskaBrzezińska and Grzywińska-Rąpca 2018]. Taking into account the above factors, organic food has become the subject of the research.

\section{METHOD}

The research was conducted in the period from February to July 2021 in eight commercial facilities in Warsaw. The research covered specialist stores with organic food (store 'A' - six locations), discounters (store 'B' - four locations) and a large-area store (store ' $\mathrm{C}$ ' - one location).

In order to assess the correct functioning of the FIFO system, inspections were carried out, during which the way of placing organic products on the shelves (excluding food intended for children) was checked.

The inspections were unannounced so that it was possible to realistically assess the functioning of the FIFO system in the institutions examined. During visits to the stores, photographic documentation was made to confirm the revealed irregularities. If it was not possible to take a photo, the deficiencies were recorded in a previously prepared form.

\section{RESULTS}

According to the report of the Federation of Polish Food Banks, food products which are most often thrown away by stores include: bread, fruits and vegetables, fresh, unpackaged meat, poultry and fish and refrigerated products with a very short expiry date.

The main cause of food waste in retail stores is that food products exceed the use-by date or the best-before date. This is the reason for throwing away fresh products, such as milk or cold cuts (58.6\%), packaged bread (46\%), and dry products, such as flour, groats or pasta (51.7\%). Another factor contributing to food waste is the freshness of products. For this reason, fruits and vegetables (78.2\%), fresh poultry and fish meat (46\%), fresh poultry and fish meat in packs (46\%) and bread (27.5\%) are wasted.

Store ' $A$ ' had six inspections conducted at six different locations. Irregularities in the functioning of the FIFO system were discovered in each store. The chart shows the detected irregularities:

The first inspection revealed irregularities in the setting of the plant-based drink. In the other store, it was also plantbased milk, but in this case, it was three different products. In the third store, cereal products and vegetable paste were placed incorrectly, and in the fourth, rice crackers and corn wafers. During the fifth inspection, not only was the wrong setting of the products noticed - three types of nut pastes (peanut butter, protein coconut paste, protein nut paste), muesli, nut bars and corn wafers - but also two exceeded shelf-life products, protein coconut paste and protein nut paste. In the sixth location, an incorrect alignment was revealed: peanut butter, $100 \%$ coconut paste, nut and dates paste, hazelnut paste, hazelnut, dates and cocoa paste, protein nut paste, muesli, rice wafers and cereal products. Table 3 presents irregularities in the functioning of the FIFO based on the use-by dates of food products.

In each inspected store, irregularities in the functioning of the FIFO were revealed, but the profile and number of products varied depending on the location. The errors in 
Table 1. Assessment of the frequency of waste of selected categories of food products in retail stores [\%]

\begin{tabular}{|c|c|c|c|c|c|c|}
\hline \multirow{2}{*}{ Specification } & \multicolumn{7}{|c|}{ Answers } \\
\cline { 2 - 7 } & Daily & $\begin{array}{c}\mathbf{2 - 3} \text { times a } \\
\text { week }\end{array}$ & $\begin{array}{c}\mathbf{2 - 3} \text { times a } \\
\text { month }\end{array}$ & $\begin{array}{c}\mathbf{2 - 3} \text { times a } \\
\text { year }\end{array}$ & $\begin{array}{c}\text { Less } \\
\text { frequently }\end{array}$ & $\begin{array}{c}\text { Lack of } \\
\text { losses }\end{array}$ \\
\hline Fruits and vegetables & 48,3 & 34,5 & 8,0 & 3,4 & 1,1 & 3,4 \\
\hline $\begin{array}{c}\text { Fresh meat, poultry and } \\
\text { fish (unpackaged) }\end{array}$ & 37,9 & 23,0 & 11,5 & 3,4 & 3,4 & 10,3 \\
\hline $\begin{array}{c}\text { Fresh meat, poultry } \\
\text { and fish (e.9. vacuum- } \\
\text { packed, MAP- Modified } \\
\text { Atmosphere Packaging) }\end{array}$ & 25,3 & 29,9 & 17,2 & 11,5 & 3,4 & 6,9 \\
\hline $\begin{array}{c}\text { Refrigerated products } \\
\text { with a very short expiry } \\
\text { date (e.g. fresh milk, } \\
\text { unpackaged sausages) }\end{array}$ & 34,5 & 23,0 & 26,5 & 3,4 & 6,9 & 1,1 \\
\hline $\begin{array}{c}\text { Refrigerated products } \\
\text { with a longer expiry date }\end{array}$ & 23,0 & 26,4 & 23,0 & 13,8 & 10,3 & 1,1 \\
\hline $\begin{array}{c}\text { Refrigerated ready-made } \\
\text { products, delicatessen }\end{array}$ & 24,1 & 24,1 & 25,3 & 6,9 & 8,0 & 4,6 \\
\hline Frozen products & 20,7 & 10,3 & 20,7 & 13,8 & 26,4 & 5,7 \\
\hline Bread (including baked & 60,9 & 14,9 & 6,9 & 4,6 & 6,9 & 1,1 \\
\hline sweet rolls) & 29,9 & 23,0 & 23,0 & 6,9 & 4,6 & 2,3 \\
\hline Bread (packaged, toasted) & 29,0 & 10,3 & 23,0 & 12,6 & 28,7 & 5,7 \\
\hline Drinks & 18,4 & 8,0 & 24,1 & 16,1 & 24,1 & 5,7 \\
\hline Dry products & 19,5 & & & & \\
\hline
\end{tabular}

Ref.: Report of the Federation of Polish Food Banks Nie Marnuj Jedzenia 2020 (table no 9) [2].

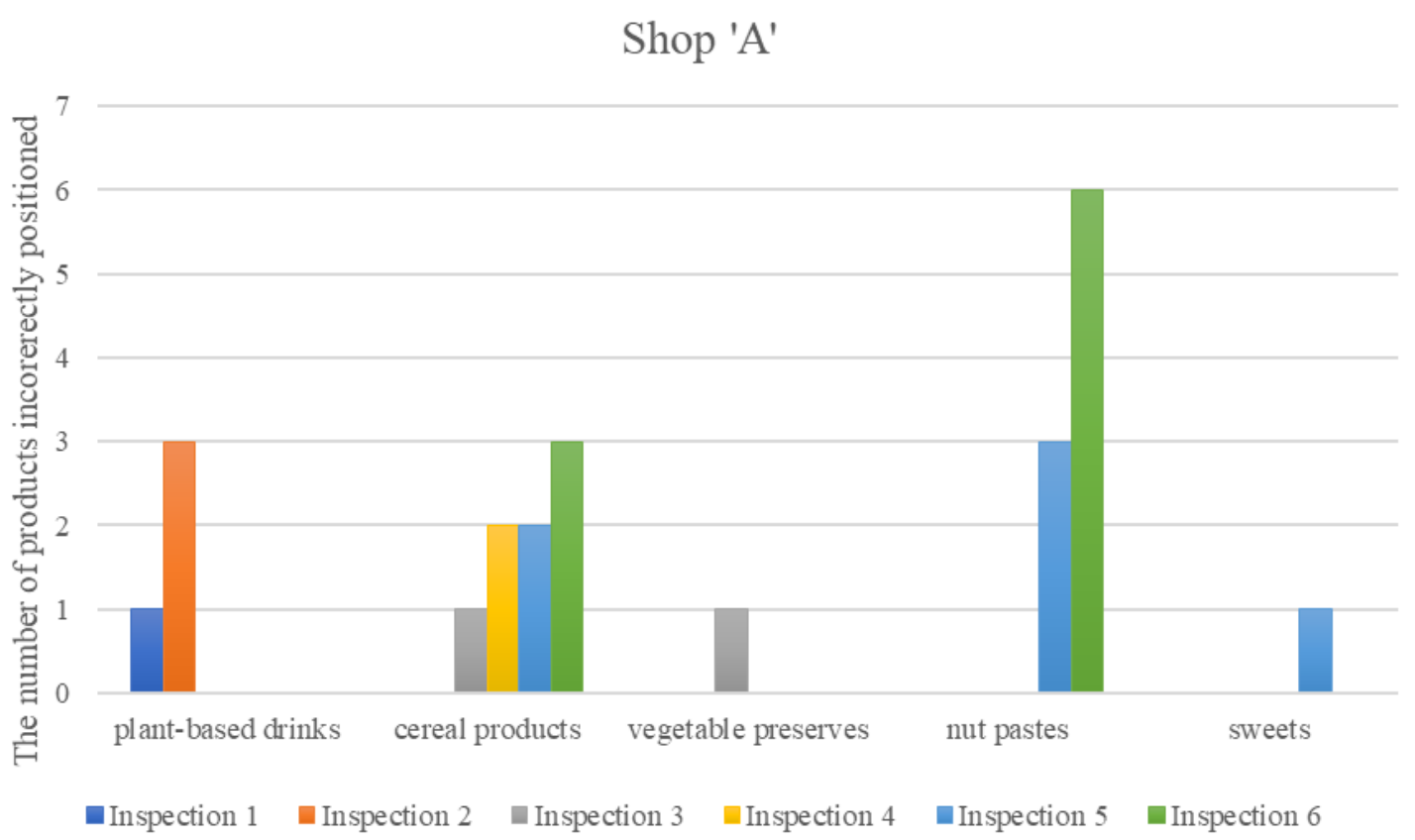

Figure 1. Products set on store shelves against the FIFO principle 
Table 2. Reasons for food waste in retail stores by product category [\%]

\begin{tabular}{|c|c|c|c|c|c|}
\hline \multirow[b]{2}{*}{ Specification } & \multicolumn{5}{|c|}{ Answers } \\
\hline & $\begin{array}{l}\text { Exceeding the } \\
\text { expiry date / date of } \\
\text { minimum durability }\end{array}$ & $\begin{array}{l}\text { Mechanical } \\
\text { damage to } \\
\text { packaging }\end{array}$ & $\begin{array}{l}\text { Failure to } \\
\text { provide } \\
\text { appropriate } \\
\text { storage } \\
\text { conditions }\end{array}$ & $\begin{array}{l}\text { Break in the } \\
\text { cold / freezing } \\
\text { chain }\end{array}$ & $\begin{array}{l}\text { Freshness } \\
\text { loss }\end{array}$ \\
\hline Fruits and vegetables & 5,7 & 6,9 & 3,4 & 2,3 & 78,2 \\
\hline $\begin{array}{l}\text { Fresh meat, poultry and fish } \\
\text { (unpackaged) }\end{array}$ & 21,8 & 3,4 & 2,3 & 9,2 & 46,0 \\
\hline $\begin{array}{c}\text { Fresh meat, poultry and } \\
\text { fish (e.g. vacuum-packed, } \\
\text { MAP- Modified Atmosphere } \\
\text { Packaging) }\end{array}$ & 42,5 & 8,0 & 4,6 & 8,0 & 20,8 \\
\hline $\begin{array}{l}\text { Refrigerated products with } \\
\text { a very short expiry date } \\
\text { (e.g. fresh milk, unpackaged } \\
\text { sausages) }\end{array}$ & 58,6 & 9,2 & 5,7 & 8,0 & 11,5 \\
\hline $\begin{array}{l}\text { Refrigerated products with a } \\
\text { longer expiry date }\end{array}$ & 51,7 & 20,7 & 2,3 & 9,2 & 11,4 \\
\hline $\begin{array}{l}\text { Refrigerated ready-made } \\
\text { products, delicatessen }\end{array}$ & 48,3 & 14,9 & 8,0 & 8,0 & 10,3 \\
\hline Frozen products & 33,3 & 20,7 & 10,3 & 26,4 & 4,5 \\
\hline $\begin{array}{l}\text { Bread (including baked } \\
\text { sweet rolls) }\end{array}$ & 18,4 & 1,1 & 1,1 & 4,6 & 65,3 \\
\hline Bread (packaged, toasted) & 46,0 & 10,3 & 3,4 & 2,3 & 27,5 \\
\hline Drinks & 55,2 & 28,7 & 1,1 & 2,3 & 5,7 \\
\hline Dry products & 51,7 & 31,0 & 3,4 & 1,1 & 3,4 \\
\hline
\end{tabular}

Ref.: Report of the Federation of Polish Food Banks Nie Marnuj Jedzenia 2020 (table no 10) [2].

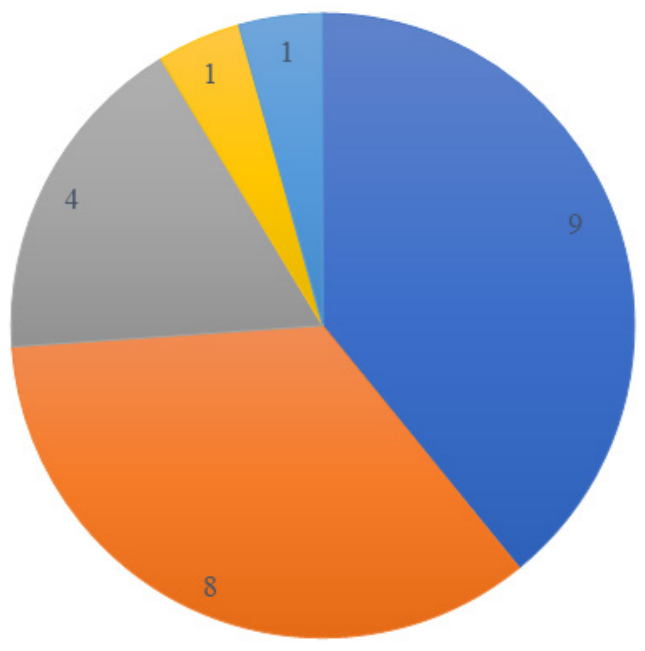

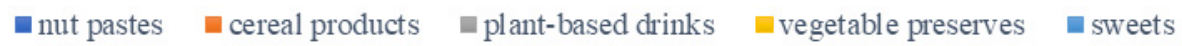

Figure 2. Products set on store shelves against the FIFO principle 
Table 3. Best before dates for products incorrectly positioned on shelves in 'A' stores. * - products with exceeded useby date

\begin{tabular}{|c|c|c|}
\hline \multicolumn{3}{|c|}{ Shop 'A' } \\
\hline Product & Date of products lined up in front & $\begin{array}{c}\text { Date of products lined up in the } \\
\text { back }\end{array}$ \\
\hline \multicolumn{3}{|c|}{ Date of inspection: 8.04 .21} \\
\hline Plant-based drink & 5.10 .21 & 25.08 .21 \\
\hline \multicolumn{3}{|c|}{ Date of inspection: 20.04 .21} \\
\hline Plant-based drink & 5.02 .22 & 21.12 .21 \\
\hline Plant-based drink & 7.03 .22 & 21.01 .22 \\
\hline Plant-based drink & 13.12 .21 & 10.09 .21 \\
\hline \multicolumn{3}{|c|}{ Date of inspection: 26.04 .21} \\
\hline Vegetable paste & 7.03 .2022 & 10.02 .2022 \\
\hline Cereal products & 03.2022 & 01.2022 \\
\hline \multicolumn{3}{|c|}{ Date of inspection: 28.05 .21} \\
\hline Rice crackers & 27.04 .22 & 11.01 .22 \\
\hline Corn wafers & 11.05 .22 & 15.03 .22 \\
\hline \multicolumn{3}{|c|}{ Date of inspection: 12.07 .21} \\
\hline Nut bar & 15.02 .22 & 15.11 .21 \\
\hline Corn wafers & 01.10 .21 & 05.09 .21 \\
\hline Muesli & 04.22 & 10.21 \\
\hline Protein coconut paste & 19.10.21 & $30.06 .21 *$ \\
\hline Protein nut paste & 5.09 .21 & $12.06 .21 *$ \\
\hline \multicolumn{3}{|c|}{ Date of inspection: 13.07 .21} \\
\hline Peanut butter & 5.05 .22 & 23.10 .21 \\
\hline $100 \%$ coconut paste & 21.04 .22 & 30.10 .21 \\
\hline Nut and dates paste & 9.01 .22 & 21.11 .21 \\
\hline Hazelnut paste & 26.02 .22 & 11.01.22 \\
\hline Hazelnut, dates and cocoa paste & 24.03 .22 & 22.01 .22 \\
\hline Protein nut paste & 23.01 .22 & 12.12 .21 \\
\hline Rice wafers & 06.22 & 04.22 \\
\hline Cereal products & 29.03 .21 & 8.03 .22 \\
\hline Muesli & 11.05 .22 & 9.04 .22 \\
\hline
\end{tabular}

Source: own elaboration

the setting most often concerned nut pastes (9), cereal products (8) and plant-based drinks (4).

At store' $B$ ', four inspections were conducted at four different locations. During each, irregularities in the functioning of the FIFO system were found. Depending on the location, the errors in the arrangement of products concerned articles of different categories. During the first inspection, irregularities in the functioning of the FIFO were found in: yoghurt, oat dessert, oat flakes and oat drinks. In the next location, the errors were recorded for plant-based drinks and olive oil. During the third inspection, errors were found in plant-based drinks, wheat flour and jam. However, in the fourth location, irregularities were for honey, jam and four types of juice.
Table 4 presents irregularities in the functioning of the FIFO based on the use-by dates of food products.

One inspection was conducted at store ' $C$ ' during which 10 irregularities in the arrangement of products were found. Irregularities in the functioning of the FIFO system were found for products, such as bread, coffee beans, muffins, cream soup, two types of plant-based drinks, soy dessert, eggs and two types of cheese.

Table 5 presents irregularities in the functioning of the FIFO based on the use-by dates of food products.

The 11 inspections carried out in three different categories of shops revealed a total of 47 products set incorrectly on the shelves. FIFO errors were most common in the case of cereal products, vegetable drinks and nut pastes - foods 
The chart shows the detected irregularities:

\section{Shop 'B'}

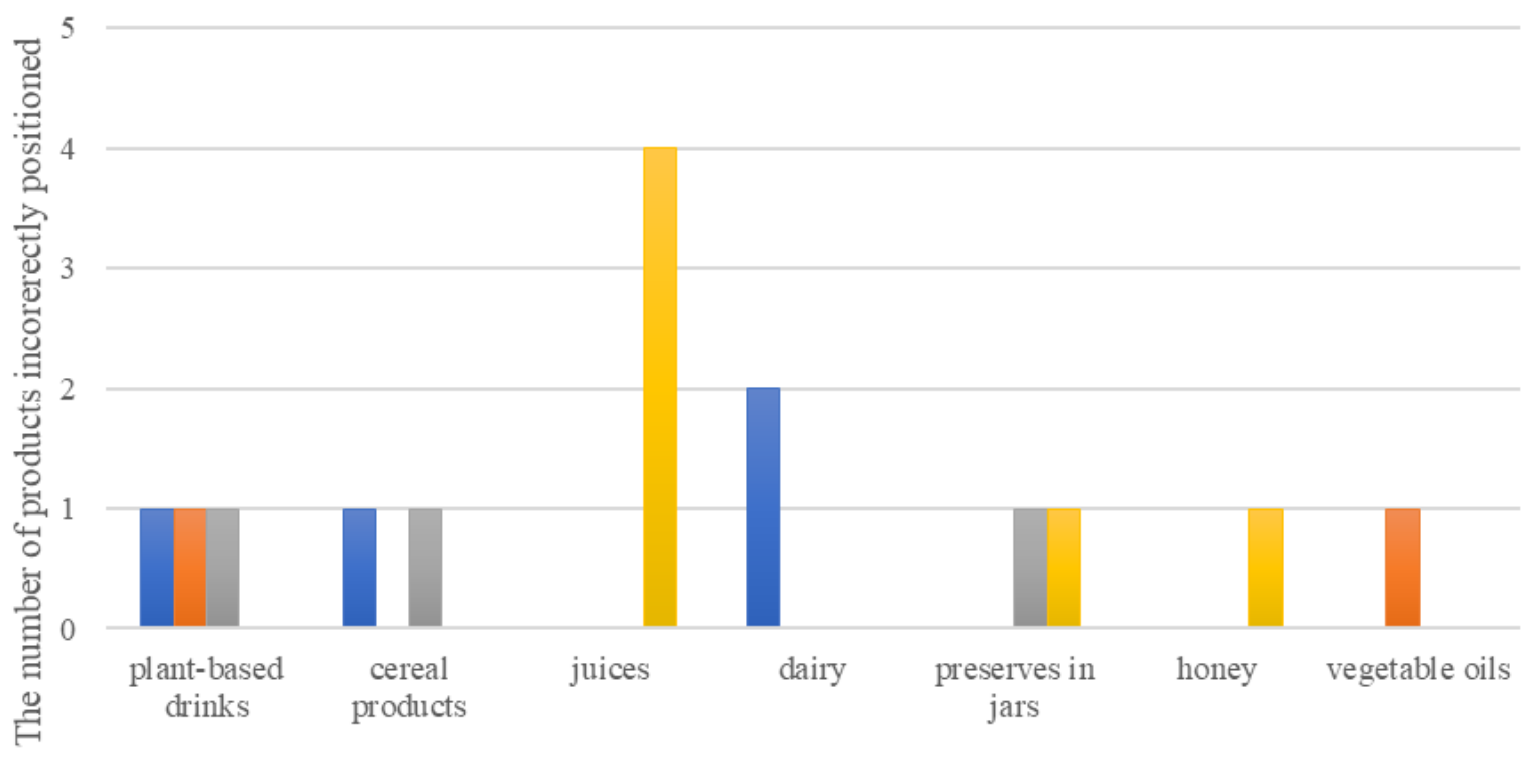

Inspection 1 Inspection 2 Inspection $3 \quad$ Inspection 4

Figure 3. Products set on store shelves against the FIFO principle

Table 4. Best before dates for products incorrectly positioned on shelves in 'B' stores. * - products with exceeded useby date

\begin{tabular}{|c|c|c|}
\hline \multicolumn{3}{|c|}{ Shop 'B' } \\
\hline Product & Date of products lined up in front & Date of products lined up in the back \\
\hline \multicolumn{3}{|c|}{ Date of inspection: 2.03 .21} \\
\hline Yoghurt & 22.03 .21 & 18.03.21 \\
\hline Oat desserts & 6.04 .21 & 5.04 .21 \\
\hline Oat flakes & 14.10 .21 & 24.07 .21 \\
\hline Plant-based drinks & 27.09 .21 & 30.08 .21 \\
\hline \multicolumn{3}{|c|}{ Date of inspection: 1.04 .21} \\
\hline Plant-based drinks & 17.04 .21 & 13.04 .21 \\
\hline Olive oil & 8.12 .21 & 23.11 .21 \\
\hline \multicolumn{3}{|c|}{ Date of inspection: 12.04 .21} \\
\hline Plant-based drinks & 13.04 .21 & 20.04 .21 \\
\hline Wheat flour & 12.03 .22 & 21.07 .22 \\
\hline Jam & 9.12 .21 & 10.12 .21 \\
\hline \multicolumn{3}{|c|}{ Date of inspection: 1.07.21 } \\
\hline Honey & 18.12 .22 & 15.11 .22 \\
\hline Jam & 23.09 .22 & 12.03 .22 \\
\hline Juice & 30.09 .21 & 25.11 .21 \\
\hline Juice & 28.01 .22 & 24.09 .21 \\
\hline Juice & 2.03 .22 & 10.11 .22 \\
\hline Juice & 24.02 .22 & 2.12 .21 \\
\hline
\end{tabular}

Source: own elaboration 
Table 5. Best before dates for products incorrectly positioned on shelves in ' $C$ ' stores. * - products with exceeded useby date

\begin{tabular}{|c|c|c|}
\hline \multicolumn{3}{|c|}{ Shop ' $C^{\prime}$} \\
\hline \multicolumn{2}{|c|}{ ' Date of inspection: 31.05.21 } \\
\hline Bread & 1.10 .21 & 7.08 .21 \\
\hline Coffee beans & 1.2022 & 1.2021 \\
\hline Muffins & 8.2021 & 7.2021 \\
\hline Cream soup & 11.05 .22 & 19.07 .22 \\
\hline Plant-based drinks & 2.04 .22 & 26.03 .22 \\
\hline Plant-based drinks & 22.01 .22 & 16.10 .22 \\
\hline Soy desserts & 3.02 .22 & 27.01 .22 \\
\hline Eggs & 14.06 .21 & 10.06 .21 \\
\hline Cheese & 31.07 .21 & 17.07 .21 \\
\hline Cheese & 19.01 .22 & 4.11 .21 \\
\hline
\end{tabular}

Source: own elaboration

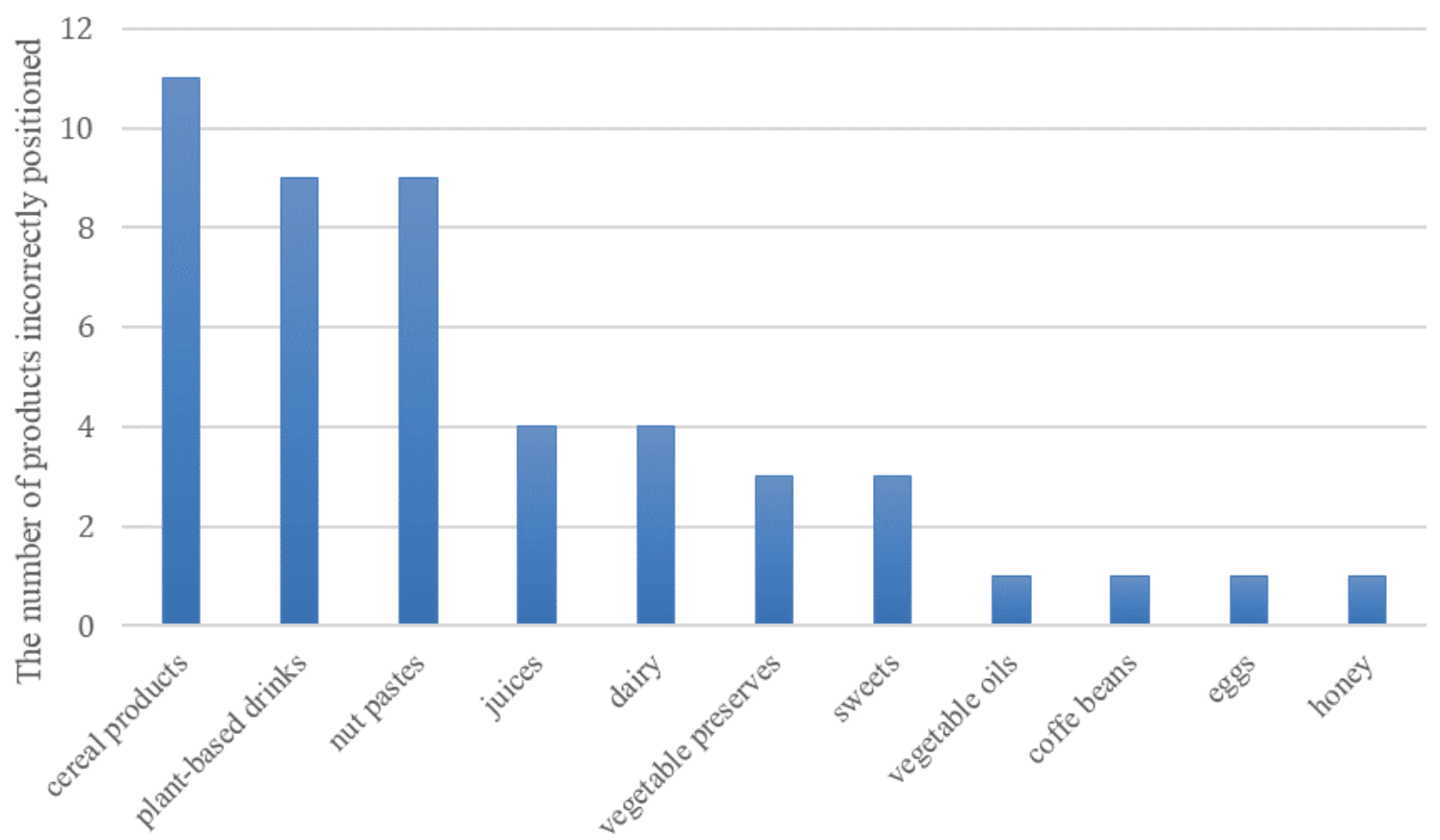

Figure 4. Products set contrary to the FIFO rule - summary of all inspections

with an extended shelf life. Despite this, two products with exceeded use-by date were found among them.

\section{CONCLUSIONS}

The assessment of the correct functioning of the FIFO was difficult, among others, due to the type and arrangement of products. In some stores it was also particularly difficult to check the positioning of plant-based drinks. The cardboard boxes were placed on very narrow and long shelves. Checking the expiry date of the product standing at the end of the rack was impossible due to the necessity to remove all other packages.

Irregularities in the functioning of FIFO were revealed in all controlled shops. The inspections carried out in Store ' $A$ ' showed that failure to apply the FIFO principle leads to the exceeded use-by date of products on store shelves. Both expired products were foods with long expiry dates; therefore, it can be assumed that in the inspected location, irregularities in warehouse logistics have been present 
for a long time, and the arrangement of goods on the shelves is not controlled. This may be due to the lack of or inadequately conducted training and improper work of the managerial staff. In Store ' $B$ ', there was repeated error in the arrangement of plant-based drinks. Errors in the functioning of the FIFO in this case were found during three out of four inspections. This proves that, regardless of the location of the store, there are irregularities in the arrangement of plant-based drinks in accordance with the FIFO system. During the inspection in Store ' $C$ ', which was a large-area store, irregularities in the functioning of the FIFO system were detected in many product categories. Egg and dairy positioning errors were detected, while Stores ' $A$ ' and ' $B$ ' had no problem lining up items in these categories according to the FIFO system.
Failure to comply or lack of appropriate procedures for the logistics of refilling the shelves leads to the expiry date of the food products being exceeded and their placing on the market. The FIFO system should be used obligatorily, also in the case of products with an extended use-by date. Proper development, implementation and control of solutions for the logistics of replenishment of organic products can reduce food wastage in retail.

\section{REFERENCES}

A Global Language for Packaging and Sustainability. 2011. A framework and a measurement system for our industry. The Consumer Goods Forum. https:// www.theconsumergoodsforum.com/wp-content/ uploads/2018/05/Global-Packaging-Report-2011.pdf [access 27.08.2021].

BERTOLINI M., BOTTANI E., RIZZI A., VOLPI A., RENZI P. 2013. Shrinkage reduction in perishable food supply chain by means of an RFID-based FIFO management policy. International Journal of RF Technologies 5, 3-4: 123136.

CORSTEN D., GRUEN T. 2003. Desperately Seeking Shelf Availability: An Examination of the Extent, the Causes, and the Efforts to Address Retail Out-ofStocks. International Journal of Retail \& Distribution Management 31, 12: 605-617.

DERQUI B., FAYOS T., FERNANDEZ V. 2016. Towards a More Sustainable Food Supply Chain: Opening up Invisible Waste in Food Service. Sustainability 8, 7: 693.

Federacja Polskich Banków Żywności: Nie marnuj jedzenia. 2020. Raport Federacji Polskich Banków Żywności. Banki Żywności. https://bankizywnosci.pl/wp-content/ uploads/2020/10/Raport_NieMarnujJedzenia_2020. pdf access [27.08.2021]

FILIMONAU, V., GHERBIN, A. 2017. An exploratory study of food waste management practices in the UK grocery retail sector. Journal of Cleaner Production, 167: 11841194.

GRZYBOWSKA-BRZEZIŃSKA M., GRZYWIŃSKA-RAPCA M. 2018. Rynek żywności ekologicznej w aspekcie rozwoju zjawiska świadomej konsumpcji. Handel Wewnętrzny 2, 373: 168-177.

HERMSDORF D., ROMBACH M., BITSCH V. 2017. Food waste reduction practices in German food retail. British Food Journal, 119: 2532-2546.

KOŁOŻYN-KRAJEWSKA D., WRZOSEK M., BILSKA B., KRAJEWSKI K., 2014. Ryzyko powstawania strat i marnotrawstwa żywności a możliwość ich ograniczenia.
Technologia produkcji i bezpieczeństwo żywności. PTTŻ, Kraków, 5-16.

MENDES A., CRUZ J., SARAIVA T., LIMA T. M., GASPAR P. D. 2020. Logistics strategy (FIFO, FEFO or LSFO) decision support system for perishable food products. International Conference on Decision Aid Sciences and Application (DASA): 173-178.

STANIAK S. 2014. Charakterystyka żywności produkowanej w warunkach rolnictwa ekologicznego. Polish Journal of Agronomy 19: 25-35.

TELLER C., HOLWEG C., REINER G., KOTZAB H. 2018. Retail store operations and food waste. Journal of Cleaner Production 185: 981-997.

TRAUTRIMS A., GRANT D. B., FERNIE J., HARRISON T. 2009. Optimizing On-Shelf Availability for Customer Service and Profit. Journal of Business Logistics 30, 2: 231 - 247.

WEI C., ASIAN S., ERTEK G., HU Z.-H. 2020. Location-based pricing and channel selection in a supply chain: a case study from the food retail industry. Annals of Operations Research 291, 1: 959-984.

WIKSTROM F, WILLIAMS H, VERGHESE K, CLUNE S. 2014. The influence of packaging attributes on consumer behaviour in food-packaging life cycle assessment studies - a neglected topic. Journal of Cleaner Production, 73: 100-108.

WRZOSEK M., BILSKA B., KOŁOŻYN-KRAJEWSKA D., KRAJEWSKI K., KONDRASZUK A. 2014. Określenie skali i przyczyn strat żywności $w$ handlu detalicznym na przykładzie mleka i jego przetworów. Żywność. Nauka. Technologia. Jakość 2,93: 225-238

VERGHESE K., LEWIS, H., LOCKREY, S., WILLIAMS, H. 2015. Packaging's Role in Minimizing Food Loss and Waste Across the Supply Chain. Packaging Technology and Science 28, 7: 603-620.

VIJAYAN G. 2014. Sustainability in Food Retail Industry through Reverse Logistics. International Journal of Supply Chain Management 2, 3: 11-23. 